\title{
Occurrence of cestode larvae in brown trout after stocking in a large regulated lake in northern Finland
}

\author{
R. Rahkonen ${ }^{1, *}$, P. Koski ${ }^{2}$ \\ ${ }^{1}$ Finnish Game and Fisheries Research Institute, PO Box 4, FIN-00721 Helsinki, Finland \\ ${ }^{2}$ National Veterinary and Food Research Institute, Oulu Regional Laboratory, PO Box 517, FIN-90101 Oulu, Finland
}

\begin{abstract}
The aim of this study was to obtain relevant information on larval cestode infection of brown trout Salmo trutta m. lacustris, for fish stock management purposes in the large, regulated Lake Inari in northern Finland. Compensatory stockings of brown trout have been carried out annually since the mid-1970s. A total of 209 brown trout, which were stocked at the age of 3 yr, were studied for larval cestodes in 1994 and 1995. Diphyllobothrium dendriticum was clearly dominant among the 4 cestode larval species found. The other species were $D$. ditremum. Triaenophorus crassus and $T$ nodulosus. After 1 summer in the lake the prevalence of $D$. dendriticum infection was $75 \%$ (abundance 5.3) and $46 \%$ (abundance 0.9) in 1994 and 1995, respectively. After 3 or more years in the lake ( $\geq 6+$ ) every brown trout was infected with a mean number of about 130 larvae for both years. All organs in the body cavity were found to be infected. In addition, capsules containing $D$. dendriticum were found in muscles after the second summer in the lake and the prevalence of muscle infection was $73 \%$ (abundance 3.2) and $95 \%$ (abundance 7.1) in the oldest age group $(\geq 6+)$ in 1994 and 1995, respectively. This has decreased the commercial value of the brown trout. A slight positive correlation between the number of $D$. dendriticum and the condition index (Fulton) of fish was found in each age group, although histological studies of heavily infected fish revealed severe chronic granulomatous peritonitis. Indications of elimination of individuals most heavily parasitized with $D$. dendriticum were not obtained for the present material. $D$. dendriticum was not found in the potential prey fishes of the brown trout studied in Lake Inari: vendace Coregonus albula, whitefish Coregonus sp. and nine-spined stickleback Pungitius pungitius.
\end{abstract}

KEY WORDS: Salmo trutta m. Lacustris - Brown trout - Diphyllobothrium dendriticum - Diphyllobothrium ditremum - Triaenophorus crassus - Triaenophorus nodulosus · Regulated lake · Stocking

\section{INTRODUCTION}

Lake Inari is a large, oligotrophic lake in northern Finland. Regulation of the water level began in the 1940 s and has been shown to strongly affect the bottom fauna in the littoral zone of the lake (Toivonen 1966, Hiisivuori \& Honkasalo 1977). This in turn has reduced the available food for fish, and annual catches of fish declined dramatically in the 1950s and onwards (Toivonen 1966). Since the mid-1970s, the damage to

\footnotetext{
•E-mail: riitta.rahkonen@rktl.fi
}

fish stocks and fisheries obviously caused by regulation has been mitigated with annual stockings of local brown trout Salmo trutta m. lacustris (L.), for example (Mutenia 1995). Brown trout catches were high in the 1980 s because of a strong vendace Coregonus albula L. stock which provided a good food supply for the brown trout (Mutenia 1995). Since 1991 the vendace stock, as well as the local whitefish stock, has been weak (because of the natural stock fluctuation) and for this reason the catches of brown trout have declined dramatically (Mutenia 1995). In addition, the brown trout have been infected with increasing amounts of larval cestode capsules in their body cavity and mus- 
cles, creating adverse effects on the commercial value of the fish (A. Mutenia \& E. Salonen pers. comm.). Previous heavy Diphyllobothrium dendriticum (Nitzsch, 1824) infections were reported from Lake Inari in the 1960s (Bylund 1966), when the stocks of the predatory fish species were also very low (Mutenia 1995). However, no parasitological study has been undertaken since.

It has been suggested that the regulation of lakes tends to favour cestode populations in fish (e.g. Petersson 1971), since the destruction of littoral bottom fauna forces many fish species to feed more on plankton, including copepods, which are the first intermediate hosts for cestodes. On the other hand, Wisniewski (1958) and Esch (1971) have suggested that larval parasites which mature in birds or mammals, like $D i$ phyllobothrium species, are more common in eutrophic bodies of water than in oligotrophic ones. The reports on mass occurrences of $D$. dendriticum and $D$. ditremum (Creplin, 1825) (Vik 1957, Halvorsen 1970, Bylund 1972, Henricson 1977, 1978, Curtis 1983, Bérubé \& Curtis 1986, Gustafsson 1996) in salmonids suggest, however, that there might be other factors of influence in the oligotrophic northern lakes which favour Diphyllobothrium species.

The aim of this study was to obtain relevant information on the larval cestode infection of brown trout for fish stock management purposes. Firstly, we wanted to examine the composition and infection level of the larval cestode species, allogenic Diphyllobothrium dendriticum and $D$. ditremum (maturing in birds and mammals) and autogenic Triaenophorus crassus Forel, 1868 and T. nodulosus (Pallas, 1760) (maturing in fish) in brown trout in relation to the number of years after stocking in Lake Inari. According to the previous publications on the mass occurrence of Diphyllobothrium spp. in brown trout and Arctic char Salvelinus alpinus (L.) in northern lakes (see ref. above), our hypothesis was that Diphyllobothrium spp. would be the dominant species in Lake Inari.

Another essential question was the source of the infection in brown trout. There was only a limited amount of data available on the brown trout diet after stocking in Lake Inari; thus we considered it important to study the stomach contents of the fish as well as larval cestodes in the potential prey fishes. Planktonic copepods are the first intermediate hosts for Diphyllobothrium and Triaenophorus species, but $D$. dendriticum and to some extent also $D$. ditremum are able to re- establish themselves from prey to predatory fishes (Halvorsen \& Wissler 1973).

Pathological effects caused by Diphyllobothrium dendriticum leading to the mortality of fish have been demonstrated to take place at fish farms (Hoffman \& Dunbar 1961, Berland 1987, Sharp 1991, Rahkonen et al. 1996) and even in lakes (Duguid \& Sheppard 1944, Hickey \& Harris 1947, Fraser 1960, Bylund 1972). Consequently, we surmised that a heavy infection of larval cestodes might cause negative effects to individual fish as well as the population level, thus impairing the stocking results. Our third aim was to study the pathological changes of the infected fish, and any direct or indirect (see e.g. Anderson \& Gordon 1982) evidence of mortality.

\section{MATERIALS AND METHODS}

Study area. Lake Inari is a large $\left(1102 \mathrm{~km}^{2}\right)$ oligotrophic lake in Finnish Lapland flowing via the River Paatsjoki into the Arctic Ocean (Fig. 1). The regulation of the water level in Lake Inari began in the 1940s at power stations on the River Paatsjoki in Russia, and the water level was raised $0.5 \mathrm{~m}$ above its normal level (Mutenia \& Salonen 1994). The maximum permitted fluctuation in water level is $2.4 \mathrm{~m}$.

Fish samples. A total of 121 and 88 brown trout were caught in southern parts of Lake Inari by gill net and trawl from August to October in 1994 and 1995, respectively (Table 1 ). In the 1994 sample, 10 brood fish were also captured in a local river where they had migrated from Lake Inari to spawn. Potential prey fish of brown trout were taken by trawl and pound net in

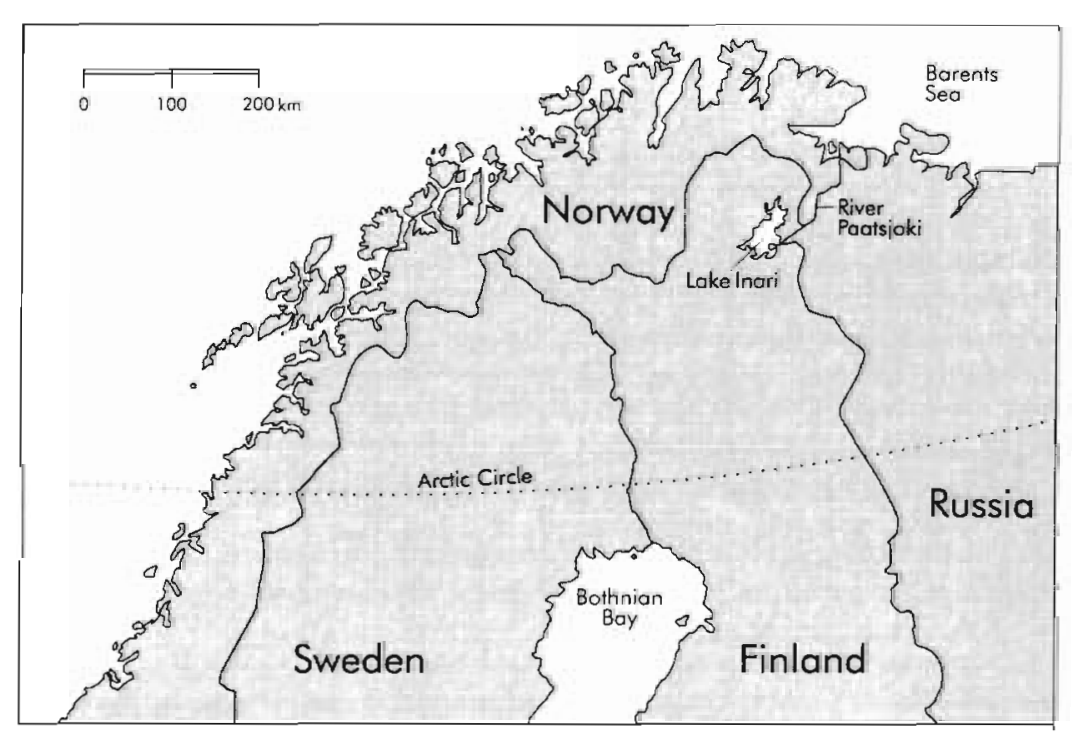

Fig. 1. Location of Lake Inari in northern Finland 
1995. A total of 222 prey fish included small whitefish Coregonus spp., vendace, and nine-spined stickleback Pungitius pungitius (L.). The fish were put into ice (about $0^{\circ} \mathrm{C}$ ) after capture. Most of the brown trout had been deep-frozen before their study in 1994, while in 1995 most of them $(61 / 88)$ and all prey fish were studied fresh.

Examination of fish. The total length and weight of the brown trout was recorded and age determination was based on the scales. For several years only 3-yr-old brown trout have been used for stocking. Consequently, at the time they were caught in autumn, fish aged $3+$ had spent 1 summer in Lake Inari, those $4+$ had spent 1 year plus 1 summer, and so on. The fish were opened, and sex and gonad developmental stages were assessed (Nikolsky 1963). The stomach of each brown trout was studied and the food items recorded macroscopically as follows: plankton, surface animals, bottom animals, and fish by species as far as possible.

Visible parasite capsules on the stomach, on and between pyloric caeca and other visceral organs were removed, counted and studied at 7 to $10 \times$ magnification using transmitted light. The stomach wall was studied thoroughly in order to find small capsules and small unencapsulated larvae in 1995. The pericardial cavity was opened and the cavity and heart were studied. Finally the skin was removed, the flesh was cut into $0.5 \mathrm{~cm}$ slices and the worms and capsules were studied.

Larval cestodes were also examined from the visceral organs of potential preyfishes: 86 small whitefish, 85 nine-spined stickleback and 51 vendace.

Live Diphyllobothrium larvae were fixed in $70 \%$ ethanol; worms from frozen fish were transferred to tap water for an hour and after species identification were preserved in $70 \%$ ethanol. Triaenophorus species were identified from the hooks

Pathology. A normal pathoanatomical necropsy procedure was performed on 6 heavily infected brown trout (length 35 to $49 \mathrm{~cm}$, weight 401 to $1063 \mathrm{~g})$ caught in September 1995. Of the organs with macroscopic lesions, samples for histology were taken into phosphate-buffered $10 \%$ formalin. Normal paraffin embedding was done after dehydration through a graded series of ethanol. Slices of $3 \mu \mathrm{m}$ thickness were stained with haematoxylin and eosin (Humason 1979).

Statistics. Computations were carried out with SYSTAT statistical software (SYSTAT 1992). For the fully factorial ANOVA model the normality of the residuals was tested with Lillefors' test and the homogeneity of variances with Cochran's test (Day \& Quinn 1989). However, in most cases valid assumptions for parametric tests were not obtained. In these cases non-parametric tests, Mann-Whitney $U$ or Kruskall-Wallis tests, were used. Differences in frequencies were tested with the likelihood ratio chisquare $\left(G^{2}\right)$ test and correlations with Spearman's rank correlation test.

\section{RESULTS}

\section{Occurrence of larval cestodes in brown trout}

Among the larval cestode species in brown trout, Diphyllobothrium dendriticum dominated, having high prevalences ( 83 to $90 \%$ ) and abundances (about 50 larvae per fish studied) in both years (Table 1). In 1995 , $D$. ditremum appeared in and on the stomach wall of every other brown trout but the abundace, 2.5, was low compared to $D$. dendriticum. In addition, a small number of very small, unidentified Diphyllobothrium larvae were encountered in the stomach wall. The amounts of $D$. ditremum as well as Diphyllobothrium sp. may be underestimated for 1994 since the method used then did not reveal the larvae inside the stomach wall. The allogenic species $D$. dendriticum and $D$. ditremum were far the more abundant than autogenic species, Triaenophorus nodulosus and T. crassus. $T$. nodulosus occurred in low numbers on the body cavity organs ( 7 and $11.5 \%$ in 1994 and 1995, respectively) and $T$. crassus in the muscles ( 5 and $1.1 \%$ ) of the brown trout (Table 1).

In the infracommunities of brown trout (see Esch et al. 1990) the number of larval cestode species per fish increased with the age of the brown trout in 1995 (Fig. 2).
Table 1. Salmo trutta m. Lacustris. Occurrence of larval cestode species in brown trout in Lake Inari in 1994 and 1995

\begin{tabular}{|c|c|c|c|}
\hline Species & $\begin{array}{l}\text { No. of fish: } \\
\text { Length, } \mathrm{cm} \text { : }\end{array}$ & $\begin{array}{c}1994 \\
121 \\
35.0\end{array}$ & $\begin{array}{c}1995 \\
88 \\
34.3\end{array}$ \\
\hline Diphyllobothrium dendriticum & $\begin{array}{l}\text { Prevalence \% } \\
\text { Abundance (SD) }\end{array}$ & $\begin{array}{c}90.0 \\
52.9(70.4)\end{array}$ & $\begin{array}{c}83.0 \\
50.2(82.1)\end{array}$ \\
\hline D. ditremum & $\begin{array}{l}\text { Prevalence \% } \\
\text { Abundance (SD) }\end{array}$ & $\begin{array}{c}21.0^{\mathrm{a}} \\
0.5(1.3)^{\mathrm{a}}\end{array}$ & $\begin{array}{c}52.9 \\
2.5(7.2)\end{array}$ \\
\hline Diphyllobothrium sp. & $\begin{array}{l}\text { Prevalence \% } \\
\text { Abundance (SD) }\end{array}$ & $\begin{array}{l}-\dot{a} \\
-{ }^{a}\end{array}$ & $\begin{array}{c}10.2 \\
0.2(0.5)\end{array}$ \\
\hline T. nodulosus & $\begin{array}{l}\text { Prevalence \% } \\
\text { Abundance (SD) }\end{array}$ & $\begin{array}{c}7.4 \\
0.2(1.1)\end{array}$ & $\begin{array}{c}11.5 \\
0.2(0.5)\end{array}$ \\
\hline T. crassus & $\begin{array}{l}\text { Prevalence \% } \\
\text { Abundance (SD) }\end{array}$ & $\begin{array}{c}5.0 \\
0.1(0.4)\end{array}$ & $\begin{array}{c}1.1 \\
0.02(0.2)\end{array}$ \\
\hline
\end{tabular}




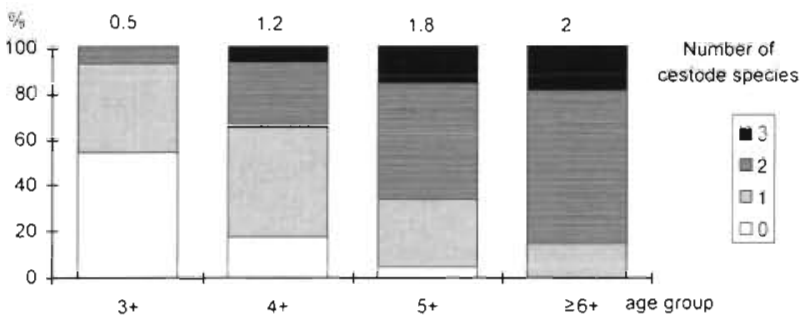

Fig. 2. Salmo trutta m. lucustris. Number of larval cestode species in brown trout in different age groups in Lake Inari in 1995. The mean number of species is indicated above the column

\section{Occurrence of Diphyllobothrium dendriticum in relation to fish age}

The relationship between fish age and the occurrence of Diphyllobothrium dendriticum larvae was studied in 4 age groups of brown trout. Prevalence increased in relation to age in both 1994 and $1995\left(G^{2}=\right.$ 12.830, $\mathrm{df}=3, \mathrm{p}=0.005$ and 19.080, $\mathrm{df}=3, \mathrm{p}<0.001$, respectively) (Fig. 3). When compared by age group, the prevalences of infection were the same in both years $\left(G^{2}\right.$-test, $\mathrm{p}>0.05$ in all cases).

The mean abundance of infection also increased significantly with fish age in 1994 and 1995 (KruskalWallis test statistic 56.212 and 58.612, respectively, $\mathrm{df}=3, \mathrm{p}<0.001$ ) and the distributions were overdispersed (variance $>$ mean) (Table 2 ). The variance-tomean ratio dropped in the oldest age group in 1994 while it increased in the same age group in 1995 . When adjusted to number of comparisons, abundances were statistically significantly lower in the $3+$ age group in 1995 compared to 1994 (Mann-Whitney $U$ test statistic $122.500, \mathrm{df}=1, \mathrm{p}=0.012$ ), but there were no significant differences in older age groups.

At the end of the first summer in the lake lage $3+$ ) small Diphyllobothrium dendriticum larvae were found mostly unencapsulated within the tissues of the outer surface of the stomach (Fig. 3). After the second lake summer $(4+)$ most of the larvae were in capsules on the stomach and other body cavity organs and the first worms were found in the muscles (i.e. clearly under the body wall). The occurrence of larvae in muscles increased with fish age, the prevalence being $73 \%$ (abundance 3.2, SD 3.4) in 1994 and 95\% (abundance 7.1, SD 10.2) in 1995 after at least 4 summers in the lake (age $\geq 6+$ ). $D$. dendriticum capsules were encountered in the lateral muscles only within the area downwards from the lateral line and in front of the ventral fins.

In the atrium of the heart 1 or 2 larvae were found mostly unencapsulated in about $13 \%$ of the $5+$ trout in both years and in $5 \%$ of the $\geq 6+$ trout in 1995 . In addition, some encapsulated larvae were found in the pericardium in 3 to $20 \%$ of the $4+$ and older trout.

Fulton's condition index [total weight $(g) \times 100 /$ total length $(\mathrm{cm})^{3}$ ] varied in age groups between 0.92 and 1.03. It seemed to increase with age except for age $4+$, when it dropped both years. The increase was significant in 1995 (ANOVA, $F_{\{3,82)}=5.37, p=0.002$ ). The number of Diphyllobothrium dendriticum larvae and the condition index correlated positively but not statistically significantly in each age group in both years (Spearman's rank correlation test, $\mathrm{p}>0.05$ ). The brood fish were omitted from the condition examination because of heavy, mature gonads. All other fish had small, immature gonads: stages 0 to 3 , using a scale of 1 to 6 according to Nikolsky (1963).

The scale analyses revealed that 8 fish aged $6+$ and older originated from wild spawners in 1994 material. Seven of them were captured as brood fish from a river draining into Lake Inari. These wild fish were excluded from the former examination and a separate comparison was made between them and those aged 6 yr and older which had been stocked into the lake as 3 -yr-olds $(\mathrm{n}=15)$. The number of Diphyllobothrium dendriticum larvae was significantly lower in wild fish than in stocked fish (Mann-Whitney $U$ test statistic 107000 , df $=1, p=0.002$ ).

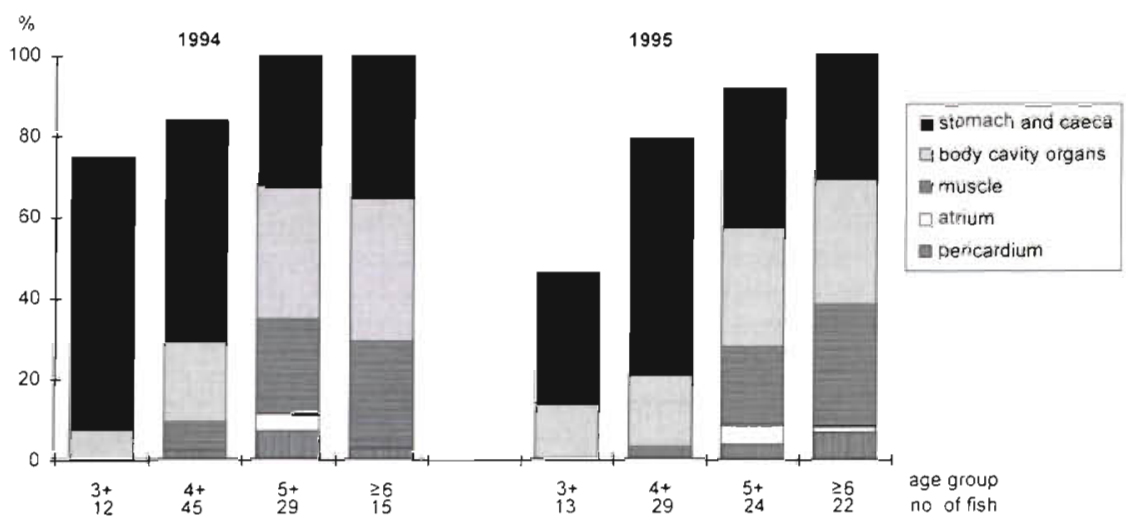

Fig. 3. Salmo trutta m. lucustris. Prevalence of infection and occurrence of $D i$ phyllobothrium dendriticum in different organs (in proportion to the height of the column) of brown trout by age group in Lake Inari in 1994 and 1995 
Table 2. Salmo trutta $\mathrm{m}$. lacustris. Occurrence of Diphyllobothrium dendriticum in brown trout in different age groups in Lake Inari in 1994 and 1995

\begin{tabular}{|c|c|c|c|c|c|c|c|c|c|c|c|c|c|c|}
\hline \multirow{3}{*}{ Age } & \multirow{3}{*}{$\begin{array}{l}\text { No. of } \\
\text { fish }\end{array}$} & \multirow{3}{*}{$\begin{array}{l}\text { Mean } \\
\text { length }\end{array}$} & \multirow{2}{*}{\multicolumn{2}{|c|}{$\begin{array}{r}1994 \\
\text { Abundance: }\end{array}$}} & \multirow[b]{3}{*}{ Min } & \multirow[b]{3}{*}{$\operatorname{Max}$} & \multirow[b]{3}{*}{ Var/mean } & \multirow{3}{*}{$\begin{array}{l}\text { No. of } \\
\text { fish }\end{array}$} & \multirow{3}{*}{$\begin{array}{l}\text { Mean } \\
\text { length }\end{array}$} & \multirow{2}{*}{\multicolumn{2}{|c|}{$\begin{array}{l}1995 \\
\text { Abundance: }\end{array}$}} & \multirow[b]{3}{*}{ Min } & \multirow[b]{3}{*}{ Max } & \multirow[b]{3}{*}{ Var/mean } \\
\hline & & & & & & & & & & & & & & \\
\hline & & & Abun. & $\mathrm{SD}$ & & & & & & Abun. & $\mathrm{SD}$ & & & \\
\hline $3+$ & 12 & 26.5 & 5.3 & 5.0 & 0 & 16 & 4.7 & 13 & 24.5 & 0.9 & 1.4 & 0 & 5 & 2.3 \\
\hline $4+$ & 45 & 31.9 & 17.2 & 21.7 & 0 & 97 & 27.4 & 29 & 28.9 & 7.4 & 14.5 & 0 & 65 & 28.4 \\
\hline $5+$ & 29 & 37.3 & 86.9 & 83.1 & 4 & 326 & 79.6 & 24 & 36.1 & 53.2 & 57.9 & 0 & 258 & 63.0 \\
\hline$\geq 6+$ & 15 & 53.4 & 128.7 & 72.8 & 33 & 258 & 41.1 & 22 & 45.1 & 132.3 & 113.6 & 27 & 425 & 97.5 \\
\hline
\end{tabular}

\section{Pathology}

All 6 brown trout subjected to the pathoanatomical examination were heavily infected and had severe chronic granulomatous peritonitis. The strongest granulomatous reactions were found in fish which had the greatest number of Diphyllobothrium plerocercoids, especially in the region of the pancreas and pyloric caeca. Fibrinous adherences between the visceral organs and the parietal peritoneum were present in 4 fish.

\section{Food composition in brown trout in 1995}

Animals collected from the surface waters, primarily ants, were the most common food items in the smallest size class. The proportion of fish in stomachs increased rapidly as the fish grew (Fig. 4). Nine-spined stickle- back was clearly the most abundant prey fish species and its proportion compared to Coregonus species increased to almost $100 \%$ among fish aged $6+$ and older.

\section{Occurrence of larval cestodes in prey fish}

Diphyllobothrium dendriticum was not found in any of the prey fish studied. Very small, unidentified Diphyllobothrium larvae occurred in and on the stomach wall of whitefish aged $0+$ (length $<7.5 \mathrm{~cm}$ ) (Table 3 ). Some $D$. ditremum larvae as well as small unidentified Diphyllobothrium specimens were found in $20 \%$ of the whitefish older than $1 \mathrm{yr}$. A few $D$. ditremum larvae occurred frequently in the liver of the nine-spined stickleback, and Schistocephalus sp. and T. nodulosus were also observed (Table 3 ). Larval cestodes did not occur in the 51 vendace studied.

Fig. 4. Salmo trutta m. lucustris. Food composition of brown trout by age group proportioned to 100\% in Lake Inari in 1994 and 1995

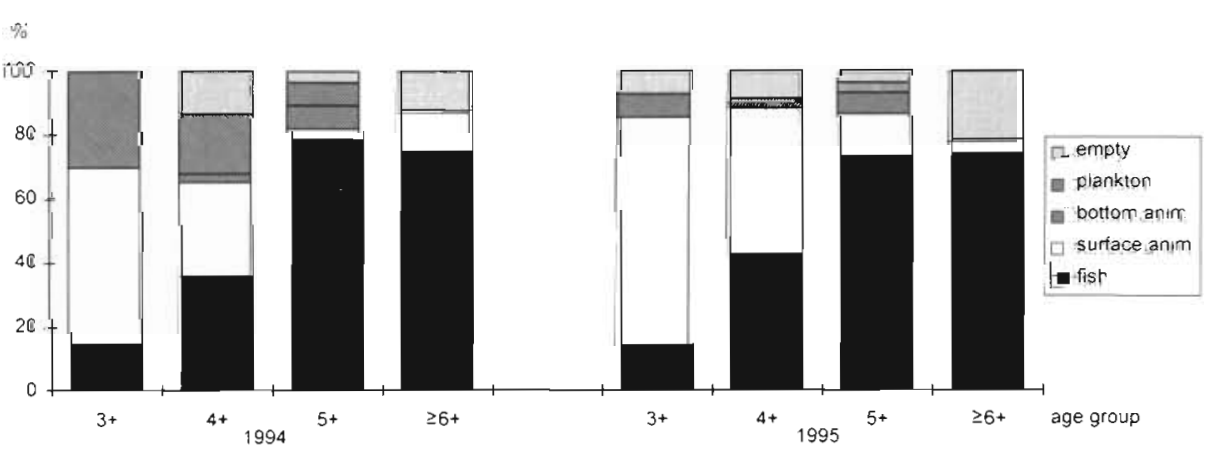

Table 3. Salmo trutta m. lacustris. Larval cestode species in the potential prey fish of brown trout in Lake Inari in 1995

\begin{tabular}{|c|c|c|c|c|c|c|c|c|c|c|c|c|c|c|}
\hline & \multirow{2}{*}{$\mathrm{n}$} & \multirow{2}{*}{$\begin{array}{c}\text { Mean } \\
\text { length } \\
(\mathrm{cm})\end{array}$} & \multicolumn{3}{|c|}{$\begin{array}{l}\text { Diphyllobothrium } \\
\text { dendriticum }\end{array}$} & \multicolumn{3}{|c|}{$\begin{array}{l}\text { Diphyllobothrium } \\
\text { sp. }\end{array}$} & \multicolumn{3}{|c|}{$\begin{array}{l}\text { Schistocephalus } \\
\text { sp. }\end{array}$} & \multicolumn{3}{|c|}{$\begin{array}{l}\text { Triaenophorus } \\
\text { nodulosus }\end{array}$} \\
\hline & & & $\begin{array}{l}\text { Prev. } \\
(\%)\end{array}$ & Abun. & $\mathrm{SD}$ & $\begin{array}{l}\text { Prev. } \\
(\%)\end{array}$ & Abun. & $\mathrm{SD}$ & $\begin{array}{l}\text { Prev. } \\
(\%)\end{array}$ & Abun. & $\mathrm{SD}$ & $\begin{array}{c}\text { Prev. } \\
(\%)\end{array}$ & Abun. & $\mathrm{SD}$ \\
\hline Whitefish $0+$ & 44 & 6.3 & 0 & 0 & 0 & 6.8 & 0.07 & 0.3 & 0 & 0 & 0 & 0 & 0 & 0 \\
\hline Whitefish $1+-2+$ & 42 & 10.2 & 21.4 & 0.3 & 0.7 & 14.3 & 0.3 & 0.7 & 0 & 0 & 0 & 0 & 0 & 0 \\
\hline $\begin{array}{l}\text { Nine-spined } \\
\text { stickleback }\end{array}$ & 85 & 4.7 & 54.1 & 1.9 & 2.9 & 0 & 0 & 0 & 17.7 & 0.2 & 0.6 & 8.2 & 0.1 & 0.3 \\
\hline
\end{tabular}




\section{DISCUSSION}

Parasite communities in salmonids have proved to be mostly dominated by autogenic parasite species and individuals (Esch et al. 1988, Hartvigsen \& Halvorsen 1993). However, Hartvigsen \& Halvorsen (1993) expected allogenic Diphyllobothrium spp. to be the core species in Norway, based on former studies by Halvorsen (1970), but $D$. dendriticum and $D$. ditremum occurred in small amounts in only 1 out of the 4 lakes studied. Although parasitological study in the present case was restricted only to the larval cestodes, allogenic Diphyllobothrium species occurred in such great numbers that it could be assumed they were the most abundant helminth species in the brown trout studied at least in the 2 oldest age groups. Curtis (1983) compared the level of Diphyllobothrium infection in Arctic char in 4 lakes in Canada and concluded that the differences in prevalence and intensity of infection between the lakes are related to the food web structures, which are influenced for instance by the number and composition of fish species in the lake. In the lakes inhabited only by Arctic char and sticklebacks, a significant proportion of the char population may become piscivorous and heavily parasitised with Diphyllobothrium by transmission from prey fish (Curtis 1983). However, no detailed study of the factors which lead to heavy infection of brown trout and Arctic char (Vik 1957, Halvorsen 1970, Bylund 1972, Henricson 1977. 1978, Curtis 1983, Bérubé \& Curtis 1986, Gustafsson 1996) in some northern lakes with either $D$. dendriticum or $D$. ditremum has been undertaken.

Diphyllobothrium dendriticum was clearly more abundant than $D$. ditremum in the present study. This was also the case in the $1960 \mathrm{~s}$, when $D$. dendriticum had a $90 \%$ prevalence in brown trout with an abundance of 100 plerocercoids (Bylund 1966). D. dendriticum and $D$. ditremum usually share the same copepod and fish species as first and second intermediate hosts (Hickey \& Harris 1947, Halvorsen 1966, 1970 , Bylund 1973, Henricson 1977, 1978, Curtis 1983, Andersen et al. 1987, Andersen \& Gibson 1989, Andersen \& Valtonen 1992). Many copepod species which have been proved to serve as intermediate hosts for $D$. dendriticum and $D$. ditremum occur in Lake Inari: Cyclops abyssorum Sars, C. lacustris Sars, C. scutifer Sars, C. strenuus Fischer and Eudiaptomus gracilis Sars (Hakkari \& Selin 1980). A remarkable difference in the life-cycle strategies of $D$. dendriticum and $D$. ditremum is, however, that the ability of plerocercoids to pass from prey fish to predatory fish is well developed in $D$. dendriticum while poor in $D$. ditremum (Vik 1957, Halvorsen 1970, Halvorsen \& Wissler 1973). As was seen in the present study in stomach samples of the brown trout, planktonic food decreased with the age of the fish and was replaced by small fishes. Although $D$. dendriticum was not found in the present data in vendace, small (stunted) whitefish or ninespined stickleback, transmission from prey fishes with low infection levels might cause accumulation of worms in brown trout. In addition, infected copepods in the stomach of any prey fish could also transport procercoids to more suitable intermediate hosts such as brown trout.

The prevalence and abundance of Diphyllobothrium dendriticum infection increased in relation to the age of the fish so that the mean number of capsules in brown trout of 6 yr and older was as high as 130 . However, according to the present results the infection level was lower for fish aged 3+ in 1995 than in 1994, which might indicate a decrease in the exposure to $D$. dendriticum larvae. When 42 brown trout aged $4+$ were studied for $D$. dendriticum, both the prevalence $(50 \%)$ and abundance of infection (2.5) remained at a low level in 1996 (Mutenia et al. 1997) cornpared to 1994 and 1995. The dynamics of $D$. dendriticum infection will be monitored annually as part of other studies in Lake Inari for the next several years to verify the alterations in the infection level relative to other changes such as variations in vendace and whitefish populations.

In the present data, a great proportion of the brown trout of a size of commercial value had Diphyllobothrium dendriticum in their muscles, which has an impact on the human consumption of the brown trout. According to the regulations of the Ministry of Agriculture and Forestry in Finland (5/EEO/94), fish purchased for human consumption must not contain visible parasites in their body cavity and muscle after gutting. $D$. dendriticum may be of particular importance as a human parasite in the Arctic and Subarctic regions (Curtis \& Bylund 1991). Its infectivity to humans has been demonstrated by Vik (1957), Bylund (1969), Halvorsen (1970) and Rausch \& Hilliard (1970). The growing popularity of lightly salted or inadequately cooked ethnic fish dishes, especially salmon, along with improved transportation systems, caused an increase in human diphyllobothriasis in Canada and the US in the 1980s (Ching 1984, Ruttenberg et al. 1984). However, thorough epidemiological studies on D. dendriticum in humans are still needed in light of the present results.

The mortality of stocked brown trout and rainbow trout due to Diphyllobothrium infection has been demonstrated in the British Isles (Duguid \& Sheppard 1944, Hickey \& Harris 1947, Fraser 1960) and in vendace in 1 eastern Finnish lake (Bylund 1972), but has not been found in Lake Inari. Even relatively small numbers of $D$. dendriticum have proved to be fatal in experiments as well as at fish farms (Kuhlov 1953 Hoffman \& Dunbar 1961, Bylund 1969, 1972, Rah- 
konen et al. 1996). D. dendriticum caused mortality, as high as $18 \%$, at a fish farm about $100 \mathrm{~km}$ southwest of Lake Inari in the 1990s after migrating into the heart of sea trout Salmo trutta m. trutta (L.) and brown trout (Rahkonen et al. 1996). In the present data some brown trout aged $4+$ and older also harboured encapsulated $D$. dendriticum larvae in the pericardium and $\leq 13 \%$ $5+$ and older had unencapsulated larvae even in the atrium. Thus, the role of larvae migrating into vital organs as a cause of mortality in the current brown trout population can neither be proved nor excluded, but needs to be studied experimentally.

Indirect evidence of the mortality of heavily parasitized individuals in the wild can be seen as a decrease in the degree of overdispersion within the older age classes of the hosts, concomitant with a decline in mean abundance (Anderson \& Gordon 1982). The latter authors used Henricson's $(1977,1978)$ data, and data from others, to suggest that the observed decrease in the mean abundance and the variance-to-mean ratios of Diphyllobothrium dendritiCum and $D$. ditremum in the oldest age groups in Arctic char was the result of host death. In the present data the variance-to-mean ratio decreased in the oldest age group in 1994 material, but the abundance of infection increased, so there was no evidence that the most heavily parasitized individuals were being eliminated from the brown trout population.

A somewhat surprising result was that the number of Diphyllobothrium dendriticum larvae and Fulton's condition index of the fish had a slight positive correlation; it seems that the more a fish eats, the more larvae it accumulates. On the other hand, the larvae and their capsules also increase the weight of the fish and because of this it would have been useful to measure the gutted weight. Heavily infected brown trout suffered from a severe inflammatory reaction in the body cavity but its real impact on condition or mortality could not be proved.

The results obtained in this study support the suggestion by local fish biologists that the number of stocked brown trout should be considerably reduced when the food supply, i.e. vendace and whitefish stocks, is poor in Lake Inari. An interesting observation in the present data is, however, that the infection level in wild brown trout was clearly lower than in stocked fish of the same age. One reason for this might be that wild fish avoid Diphyllobothrium dendriticum infection while spending 4 to $5 \mathrm{yr}$ as parrs in local rivers (see e.g. Rahkonen et al. 1996) before they enter the lake. Another explanation could be differences in the diets of wild and farmed fish. In the light of this result, increasing of brown trout stockings in rivers instead the lake might hinder, at least to some extent, $D$. dendriticum infection, but this needs to be studied.
In conclusion, the allogenic larval cestodes Diphyllobothrium dendriticum and $D$. ditremum were clearly more abundant than the autogenic Triaenophorus nodulosus and $T$. crassus in the stocked brown trout in Lake Inari. $D$. dendriticum was the dominant species and its prevalence and abundance increased with the age of the fish, concominant with the increasing proportion of prey fish in the stomach contents. However, $D$. dendriticum was not found in the prey fish species studied: whitefish, vendace and nine-spined stickleback. Two years after stocking and onwards, D. dendriticum often occurred in the muscles of brown trout, decreasing the commercial value of the fish. Direct or indirect evidence of $D$. dendriticum induced mortality was not found. There was a slight positive correlation between the number of plerocercoids and Fulton's condition index of the fish, although the heavily infected fish suffered from severe granulomatous peritonitis.

As stated by Esch \& Fernández (1993), empirical evidence to support parasite-induced host mortality in natural populations is not extensive, although some examples do exist. It is very difficult to differentiate the effects of many factors contributing to fish mortality in natural environments. One way of obtaining more detailed data about the effect of helminth parasites, $D$. dendriticum for instance, on the welfare of the host fish is to approach this subject using laboratory experiments

Acknowledgements. Our warmest gratitude to the staff of the Inari and Sarmijärvi Fish Farms and Fish Research Unit in Ivalo, especially to $\mathrm{Mr}$ Ahti Mutenia (MSc). Mr Eero Heinonen, Mr Heimo Pukkila, Mr Petri Heinimaa, Mr Erno Salonen (MSc) and Mr Markku Ahonen (MSc) for fruitful collaboration and comments on the manuscript. We are indebted to Assoc. Prof. E. T Valtonen for her valuable ideas about and criticism of the manuscript. Special thanks also to Docent G. Bylund and Mr Jarmo Aalto (MSc). Financial support was obtained from the Finnish Game and Fisheries Research Institute and the Academy of Finland.

\section{LITERATURE CITED}

Andersen K, Ching HL, Vik R (1987) A review of freshwater species of Diphyllobothrium with redescriptions and the distribution of $D$. dendriticum (Nitzsch, 1824) and $D$. ditremum (Creplin, 1825) from North America. Can J Zool 65:2216-2228

Andersen KI, Gibson DI (1989) A key to three species of larval Diphyllobothrium Cobbold, 1858 (Cestoda: Pseudophyllidea) occurring in European and North-American freshwater fishes. Syst Parasitol 13:3-9

Andersen KI, Valtonen ET (1992) Segregation and cooccurrence of larval cestodes in freshwater fishes in the Bothnian Bay, Finland. Parasitology 104:161-168

Anderson RM, Gordon DM (1982) Processes influencing the distribution of parasite numbers within host populations with special emphasis on parasite-induced mortalities. Parasitology 85:373-398 
Berland B (1987) Helminth problems in sea-water aquaculture. In: Stenmark A, Malmberg $M$ (eds) Parasites and diseases in natural waters and aquaculture in Nordic countries. Zoo-Tax, Naturhistoriska Riksmuseet, Slockholm, p 56-62

Bérubé M. Curtis MA (1986) Transmission of Diphyllobothrium ditremum to arctic char (Salvelinus alpinus) in two subarctic Quebec lakes. Can J Fish Aquat Sci 43: $1626-1634$

Bylund G (1966) Förekomsten av difyllobotrida plerocerkoider i fisk från Enare sjö. Parasitol Inst Soc Scient Fenn, Helsinki, Tiedoksianto-Information 6:48-56 (in Swedish)

Bylund G (1969) Experimentell undersökning av Diphyllobothrium dendriticum $(=D$. Norvegicum) från norra Finland. Parasitol Inst Soc Scient Fenn, Helsinki, Tiedoksianto-Information 10:3-17 (in Swedish)

Bylund G (1972) Pathogenic effects of a diphyllobothriid plerocercoid on its host fishes. Commentat Biol Soc Sci Fenn 58:1-11

Bylund $G$ (1973) Observations on the taxonomic status and the biology of Diphyllobothrium ditremum (Creplin, 182.5) $1=D$. osmeri von Linstow, 1878). Acta Acad Abo Ser B 33: $1-18$

Ching HL (1984) Fish tapeworm infections (diphyllobothriasis) in Canada, particularly British Columbia. Can Med Assoc J 130:1125-1127

Curtis MA (1983) Parasitism of arctic char by Diphyllobothrium ditremum and $D$. dendriticum in relation to the food web structures of northern lakes. Proc Second ISACF workshop on Arctic char 1982. ISACF Information series $2: 11-18$

Curtis MA, Bylund G (1991) Diphyllobothriasis: fish tapeworm disease in the circumpolar north. Arct Med Res 50:18-25

Day RW, Quinn GP (1989) Comparisons of treatments after an analysis of variance in ecology. Ecol Monogr 59:433-463

Duguid JB, Sheppard EM (1944) A Diphyllobothrium epidemic in trout. $J$ Pathol 56:73-80

Esch GW (1971) Impact of ecological suggession on the parasite fauna in centrarchids from oligotrophic and eutrophic ecosystems. Am Mid Nat 86:160-168

Esch GW, Fernández JC (1993) A functional biology of parasitism. Ecological and evolutionary implications. Chapman \& Hall, London

Esch GW, Kennedy CR, Bush AO, Aho JM (1988) Patterns in helminth communities in freshwater fish in Great Britain: alternative strategies for colonization. Parasitology 96: $519-532$

Esch GW, Shostak AW, Marcogliese DJ, Goater TM (1990) Patterns and processes in helminth parasite communities: an overview. In: Esch G, Bush A, Aho J (eds) Parasite communities: patterns and processes. Chapman and Hall, London, p 1-19

Fraser PG (1960) The occurrence of Diphyllobothrium in trout, with special reference to an outbreak in the West of England. J Helminthol 34:59-72

Gustafsson T (1996) The effect of cestode Diphyllobothrium ditremum on growth, condition, reproduction and mortality in whitefish (Coregonus lavaretus L. s.l.) in the subarctic Lake Kilpisjärvi. MSc dissertation, University of Helsinki (in Finnish)

Hakkari L, Selin P (1980) Zooplankton studies in Lake Inari in 1979. Hydrobiologian tutkimuskeskus. University of Jyväskylä (in Finnish with English summary)

Halvorsen $O(1966)$ Studies of the helminth fauna of Norway. VIII. An experimental investigation of copepods as first intermediate host for Diphyllobothrium norvegicum Vik
(Cestoda). Nytt Mag Zool 13:83-117

Halvorsen O (1970) Studies of the helminth fauna of Norway. $X V$. On the taxonomy and biology of plerocercoids of Diphyllobothrium Cobbold, 1858. Nytt Mag Zool 18: 113-174

Halvorsen O, Wissler K (1973) Studies of the helminth fauna of Norway XXVIII: an experimental study of the ability of Diphyllobothrium latum (L.), D. dendriticum (Nitzsch), and $D$. ditremum (Creplin) (Cestoda, Pseudophyllidea) to infect paratenic hosts. Norw J Zool 21:201-210

Hartvigsen R, Halvorsen $O$ (1993) Common and rare trout parasites in a small landscape system. Parasitology 106 101-105

Henricson J (1977) The abundance and distribution of Diphyllobothrium dendriticum (Nitzsch) and $D$. ditremum (Creplin) in the char Salvelinus alpinus (L.) in Sweden. J Fish Biol 11:231-248

Henricson J (1978) The dynamics of infection of Diphyllobothrium dendriticum (Nitzsch) and $D$. ditrenum (Crepiinj in the char Salvelinus alpinus (L.) in Sweden. J Fish Biol 13: $51-71$

Hickey MD, Harris JR (1947) Progress of the Diphyllobothrium epizootic at Poulaphouca Reservoir, Co. Wicklow, Ireland. J Helminth 22:13-28

Hiisivuori C. Honkasalo L (1977) Studies on benthic invertebrates in Lake Inari in 1976. Finnish Game and Fisheries Research Institute, Helsinki (in Finnish)

Hoffman GL, Dunbar CE (1961) Mortality of eastern brook trout caused by plerocercoids (Cestoda: Pseudophyllidea: Diphyllobothridae) in the heart and viscera. J Parasitol $47: 399-400$

Humason GL (1979) Animal tissue techniques, 4th edn. WH Freeman and Co, San Francisco, p 112-122

Kuhlow F (1953) Über die Entwicklung und Anatomie von Diphyllobothrium dendriticum Nitzsch 1824. Z Parasitenkd 16:1-35

Mutenia A (1995) Lake Inarijärvi. In: Fish and game by region-regional statistics on fisheries and hunting in Finland. SVT, Ympäristö 12:44-49 (in Finnish with English summary)

Mutenia A, Salonen E (1994) Rehabilitation of the fisheries of Lake Inari, northern Finland. In: Cowx IG (ed) Rehabilitation of freshwater fisheries. Fishing News Book, Hull International Fisheries Institute, University of Hull, p $280-288$

Mutenia A, Salonen E, Maunu A, Pukkila $H$, Heinimaa $S$ (1997) Annual report of the results of the compensatory measures in the management of fish stocks and fisheries in Lake Inari and adjoining water bodies in 1996. Finnish Game and Fisheries Research Institute, Helsinki. Kala- ja riistaraportteja 91, $40 \mathrm{p}$ (in Finnish)

Nikolsky GV (1963) The ecology of fishes. Academic Press, London

Petersson $\AA$ (1971) The effect of lake regulation on populations of cestodan parasites of Swedish whitefish Coregonus. Oikos 22:74-83

Rahkonen R, Aalto J, Koski P, Särkkä J, Juntunen K (1996) Cestode larvae, Diphyllobothrium dendriticum (Nitzsch, 1824), as a cause of heart disease leading to mortality in hatchery reared sea trout and brown trout. Dis Aquat Org 25:15-22

Rausch RL, Hilliard DK (1970) Studies on the helminth fauna of Alaska. XLIX. The occurrence of Diphyllobothrium latum (Linnaeus, 1758) (Cestoda: Diphyllobothriidae) in Alaska, with notes on other species. Can J Zool 48: $1201-1219$

Ruttenberg AJ, Weniger BG, Sorvillo F, Murray RA, Ford S 
(1984) Diphyllobothriasis associated with salmon consumption in Pacific coast states. Am J Trop Med Hyg 33: 455-459

Sharp GJE (1991) Worms - a further cause for concern? Fish Farmer 14(6):42-43

SYSTAT (1992) SYSTAT for Windows: Statistics, Version 5. SYSTAT Inc, Evanston, IL

Toivonen J (1966) The impact of water level regulation on the

Editorial responsibility: Wolfgang Körting

Hannover, Germany fish stock and fishing in Lake Inari. Finnish Game and Fisheries Research Institute, Helsinki (in Finnish)

Vik R (1957) Studies of the helminth fauna of Norway I. Taxonomy and ecology of Diphyllobothrium norvecicum n. sp. and plerocercoid of Diphyllobothrium latum (L.). Nytt Mag Zool 5:25-93

Wisniewski WL (1958) Characterization of the parasitofauna of an eutrophic lake. Acta Parasit Pol 6:1-64

Submitted: January 1, 1997; Accepted: June 27, 1997 Proofs received from author(s): September 19, 1997 